\title{
Article \\ The Role of CEO Power on CSR Reporting: The Moderating Effect of Linking CEO Compensation to Shareholder Return
}

\author{
María Consuelo Pucheta-Martínez ${ }^{1, *(D)}$ and Isabel Gallego-Álvarez ${ }^{2}$ (D) \\ 1 Department of Finance and Accounting, Campus del Riu Sec s/n, Universidad Jaume I, \\ 12071 Castellón de la Plana, Spain \\ 2 Department of Business Administration, Multidisciplinary Institute for Enterprise (IME), \\ University of Salamanca, Edificio FES, 37007 Salamanca, Spain; igallego@usal.es \\ * Correspondence: pucheta@uji.es; Tel.: +34-964-38-7141
}

Citation: Pucheta-Martínez, M.C.; Gallego-Álvarez, I. The Role of CEO Power on CSR Reporting: The Moderating Effect of Linking CEO Compensation to Shareholder Return. Sustainability 2021, 13, 3197. https://doi.org/10.3390/su13063197

Academic Editor:

Abdollah Shafieezadeh

Received: 16 January 2021

Accepted: 11 March 2021

Published: 15 March 2021

Publisher's Note: MDPI stays neutral with regard to jurisdictional claims in published maps and institutional affiliations.

Copyright: (c) 2021 by the authors. Licensee MDPI, Basel, Switzerland. This article is an open access article distributed under the terms and conditions of the Creative Commons Attribution (CC BY) license (https:// creativecommons.org/licenses/by/ $4.0 /)$.

\begin{abstract}
The aim of this research was to provide further evidence of the impact of the power of the Chief Executive Officer (CEO) on corporate social responsibility (CSR) disclosure. Additionally, we explore the moderating role of CEO compensation linked to shareholder return on the association between CEO power and CSR disclosure. The theories used follow agency theory and stakeholder theory and the sample comprised 9182 international firm-year observations collected from the Thomson Reuters database from 2009 to 2018. Our model was estimated using the generalized method of moments (GMM) estimator. The results found that CEO power was positively associated with CSR disclosure, contrary to our expectations. Additionally, our evidence also shows that CEO compensation linked to shareholder return plays a positive moderating role on the relationship between CEO power and CSR reporting.
\end{abstract}

Keywords: CEO power; corporate social responsibility reporting; CEO compensation link to shareholder return; agency theory; stakeholder theory

\section{Introduction}

In recent years, the topic of corporate social responsibility (CSR) and its disclosure by international firms has attracted increasing interest across the world. Mark-Herbert and Von Schantz [1] believe that firms are increasingly aware of their social responsibility and are more motivated to integrate CSR aspects into their business. The reasons why companies disclose CSR information are varied. Authors such as Campbell [2] state that a primary motivation may be to project a responsible image to a broad range of stakeholders; by presenting CSR reports, firms meet the stakeholders' demands and also contribute to society's well-being [3,4]. Another reason for the disclosure of CSR activities is the expectation of reward in the form of long-term profitability, potentially enabling firms to improve their capacity to recruit, reassure shareholders of non-financial risk, reduce information asymmetry, or improve stakeholders' decision-making [5]. A third reason to disclose CSR information stems from a feeling of obligation to do so due to various types of institutional pressure: firms are economic units that operate in the broader context of varied institutions that have an impact on their behavior and burden them with certain expectations [2]. This explains why firms working in countries with similar institutions adopt similar behaviors. Focusing on such institutions can help to understand CSR disclosure not simply as voluntary reporting, but also as a requirement imposed by the entrepreneurial context.

Friede et al. [6] and Busch and Friede [7] have highlighted a substantial body of research addressing the association between a number of financial and managerial variables and CSR. However, as Margolis and Walsh [8] did some time ago, it is time to move on to a different line of research (e.g., Chief Executive Officer (CEO) power and CSR). 
The position of CEO has always been regarded as one of the most powerful in a firm [9]. The CEO or, more specifically, the power a CEO holds, is a key potential influence on the firm's decisions. Agency theory, among others, explains to a great extent the possible CEO effect as a result of the CEOs' power in determining the goals of a corporation including CSR reporting. In line with authors such as Finkelstein [10] and Adams et al. [11], CEO power (a powerful CEO) can be defined as the capacity of the CEO to address and overcome opposing positions, both internally (other executives and directors) and externally (uncertainty), and to influence crucial organizational decisions. CEO power may derive from the characteristics of the position, since CEOs are expected to be capable of positioning their firms to create wealth [12] and maximize future opportunities for stakeholders [13]. Saidu [14] lists the four most relevant power dimensions that may explain how CEOs can acquire power: (1) structural power (the position or office(s) they hold, such as Chair of the board, board member, CEO compensation); (2) ownership power (as a shareholder or founder); (3) expert power (familiarity with the environment brought by experience, expertise, tenure, skills or a number of positions held in firms); and (4) prestige power (the capability to absorb uncertainty from the institutional context, expressed through respect, reputation, or admiration). Further detail about how CEOs acquire power can be found in Saidu [14]. Hence, the responsibility of CEOs focuses not only on creating value for shareholders, but also for the workers and community surrounding the organization [15].

There is little existing research on the impact of CEO power (or powerful CEOs) on CSR reporting. Jiraporn and Chintrakarn [16] found that the relation between CEO power and CSR was non-monotonic because, when CEOs are relatively more powerful, CEO power and CSR disclosure are negatively related. In the same vein, Li et al. [17] reported a negative relationship between CEO power and CSR disclosure. Among firms listed on the Standard \& Poor's (S\&P) 500 Index, Sheikh [18] found that CEO power was negatively related to CSR reporting and demonstrated a significant negative association between CEO power and CSR disclosure in four social dimensions (diversity, community, environment, and employee relations) and a non-significant association in the product dimension. In the context of Bangladeshi firms, Rashid et al. [19] proved that businesses with greater levels of CEO power were negatively associated with CSR disclosure.

To date, therefore, there is little available research on the impact of CEO power on CSR disclosure. We believe that the topic merits analysis in greater depth and that further attention should be given to fill the gap in the literature on the impact of CEO power (powerful CEOs) on CSR reporting. Furthermore, the majority of past research into CEO power has addressed its effect on the firms' financial decisions, but little is known about how CEO power affects the firms' non-financial decisions such as CSR disclosure. This research, therefore, aims to provide further evidence on the role of CEO power in CSR disclosure using a sample of international firms. Additionally, we will analyze the moderating role of linking CEO compensation to shareholder return on the association between CEO power and CSR disclosure, since this moderating effect has not previously been addressed. The theories used to explain this relationship are based on agency theory and stakeholder theory, which are particularly pertinent in an analysis of how CEO power influences CSR disclosure. According to agency theory, powerful CEOs will have greater ability to influence the firms' decisions. They may use CSR practices as a means to further entrench their position and, thus, an analysis of the effect of CEO power on CSR disclosure will shed new light on the literature regarding CEO power. Conversely, stakeholder theory suggests that the CEO position is always one of the most powerful in a firm. Its power may stem from its importance because CEOs are expected to be able to position their firms to create wealth and maximize future opportunities for interest groups, but powerful CEOs may also fail to act in the best interests of shareholders and stakeholders due to personal interests [19]. This argument merits further exploration of whether powerful CEOs act against the best interests of shareholders and stakeholders by decreasing CSR disclosure. 
This research contributes to existing knowledge, first, by extending the current knowledge on how certain CEO power affects CSR disclosure, using a sample of 16 countries. Our research adds to prior studies based on single countries or specific geographical regions such as the United States, Hong Kong or Bangladesh by providing evidence about firms operating in a range of countries. In this regard, CEO power, contrary to the majority of past evidence, has a positive impact on CSR reporting. Thus, powerful CEOs do not always behave contrary to the stakeholders' needs and interests. Simultaneously, this study also contributes to the analysis of the moderating effect of linking CEO compensation to shareholder return on the relationship between CEO power and CSR disclosure, an effect that has not been addressed in previous studies, as far as we know. In this regard, our evidence shows that, for powerful CEOs, linking CEO compensation to shareholder return reinforces the positive effect of CEO power on CSR disclosure.

The rest of this paper is organized as follows. Section 2 provides a theoretical framework for the association between CEO power and CSR disclosure; Section 3 develops the hypotheses proposed in this research; Section 4 describes the sample, methodology, and variables used; Section 5 presents an analysis of the results; and, finally, and Section 6 summarizes our conclusions and the implications of our findings.

\section{Theoretical Framework}

Studies aimed at analyzing the influence of CEO power on CSR disclosure have traditionally focused on a single country. For example, the work of Rashid et al. [19] focused only on Bangladeshi firms and revealed that CEO power was negatively associated with CSR disclosure, although this negative association appeared to be positively moderated by the stakeholders' degree of influence. Thus, while CEO power reduces the level of CSR disclosure in Bangladeshi firms, stakeholder influence lessens this negative effect of CEO power on the level of CSR disclosure. Rashid et al. suggest [19] that further empirical research is required to understand the role of powerful CEOs in the disclosure of CSR information. For firms based in the USA, studies such as that by Jiraporn and Chintrakarn [16] showed that increases in CEO power are associated with greater CSR engagement. However, this trend is reversed when CEOs are extremely powerful; specifically, the above study focused on the notion that when CEOs gain power, settle in, and become entrenched, they no longer invest in CSR disclosure. Indeed, when CEO power rises above a certain threshold, the most powerful CEOs significantly reduce investment in CSR.

In a study of UK firms, Li et al. [17] found that CEO power negatively affects a firm's decision to engage in CSR disclosure. Moreover, they found that the greater the CEO's power, the lower the level of CSR activity engaged in by firms, which is diametrically opposed to the research hypothesis posed in the current study where the greater a CEO's power, the more likely it is that a firm will engage in CSR. The latter is consistent with the findings of Hong et al. [20] and Jo and Harjoto [21], who state that an increase in CEO power leads to greater CSR engagement.

As for the most common theories used to explain this relationship, agency theory and stakeholder theory have proved especially useful in analyzing how CEO power influences CSR disclosure. According to agency theory, certain managers become powerful as a result of concentrated ownership, long-term tenure, and their position as company founders as well as in some cases because they play the dual role of CEO and chairperson [22,23]. This situation can lead deep-rooted and well-established forms of CEO power to be used for or against shareholder or stakeholder interests [24,25]. In this regard, CEO dominance affects key firm outcomes and allows CEOs to act in their own interests and not necessarily in those of shareholders and stakeholders, thus worsening or accentuating the agency conflict. Powerful CEOs tend not to compromise with other top executives, and make more extreme decisions, which can negatively affect firms. Accordingly, CEO power may mitigate the board's effectiveness and power in monitoring management, weaken internal control systems, and reduce the boards' involvement in social activities. Powerful CEOs may not be motivated to invest in CSR practices if such practices are not linked to their own 
interests [26,27]. Agency theory argues that CEOs will have an interest in investing in CSR activities if their private profits increase; thus, the more powerful the CEO, the less they are expected to engage in CSR activities, but rather to focus on working to enhance their own private benefits. Thus, it can be expected that CEO power fosters managerial entrenchment and reduces reporting transparency, for instance, discouraging CSR disclosure.

Alongside agency theory, the stakeholder approach is another important theory used to analyze the relationship between CEO power and CSR disclosure. It adds to agency theory by arguing that the board of directors is responsible not only for shareholder interests, but also for those of all stakeholders: the relationship between firms and stakeholders legitimizes the latter's eligibility to participate in the firms' decision-making, so boards should represent the interests of stakeholder groups. According to Freeman [28], stakeholder theory suggests that managers engage in CSR reporting to satisfy a broader range of stakeholders such as the community and society, thus integrating social demands into the business model. In a similar vein, Harjoto and Jo [29] argued that managers engage in CSR activities to resolve conflicts between various stakeholders. The debate around CSR is more complex to understand when CEOs gain power, as that power can affect CSR reporting [19]. Hence, according to Harper and Sun [30], when CEOs become more powerful, they may not act in the best interests of stakeholders and shareholders. For Bebchuk et al. [31], when CEOs become more powerful, they are less likely to engage in CSR activities and more likely to engage in actions to maximize their own interests such as holding or even increasing their power at the expense of stakeholders and shareholders, which suggests a negative relationship between CEO power and CSR disclosure.

\section{Research Hypotheses}

3.1. Chief Executive Officer (CEO) Power as a Determinant of Corporate Social Responsibility (CSR) Reporting

According to authors such as Fiegener et al. [32], CEO power can determine board composition and influence decision-making. Similarly, Dalton and Kesner [33] argue that a powerful CEO may affect board decisions, ultimately reducing board efficacy [34]. This is possibly because CEOs often have power over board members as a result of structural and socio-psychological mechanisms that have a significant impact on decision-making at the board level [35]. This CEO power can arise from different sources [36] including CEO duality or family CEO status, among others.

Muttakin et al. [37] state that a more powerful CEO may make decisions that disregard stakeholder interests, which could result in low levels of social engagement and, therefore, affect the firms' disclosure of information. This belief is shared by Weisbach [38], who emphasizes that various ingrained forms of CEO power can be used to promote self-interest rather than those of shareholders or stakeholders.

According to Saidu [14], agency theory substantially explains the possible CEO effect, due to the CEO's power over determining the goals of a corporation such as CSR reporting. The power held by CEOs usually insulates them from disciplining and controlling forces such as boards of directors, the managerial labor market, and/or the market for corporate control [39]. Entrenched forms of CEO power may be used to advance self-interest rather than the interests of shareholders or stakeholders. As McWilliams et al. [26] suggest, powerful CEOs may not be motivated to invest in CSR practices such as CSR disclosure, if these practices are not linked to their own interests. CSR activities such as CSR disclosure are effective tools for creating firm value, in contrary to the overinvestment hypothesis and, therefore, powerful CEOs may consider investment in CSR activities as wasteful. Additionally, dominant CEOs will discourage CSR disclosure in order to minimize the public scrutiny and control of outsiders such as potential or actual investors, financial analysts, the financial press, or other relevant stakeholders. CEO power could, therefore, restrict the potential of the board to invest in CSR and disclose relevant information concerning CSR practices. 
Muttakin et al. [37] agree that CEO power is a variable with the potential to negatively influence the level of CSR disclosure by inhibiting a board's monitoring ability. In this regard, powerful CEOs may be more concerned with their own interests and the costs of CSR practices and, consequently, may negatively influence corporate decisions regarding CSR activities.

Among the studies on the relationship between CEO power and CSR disclosure, Jiraporn and Chintrakarn [16] examined the CEO pay slice (CPS) as a proxy for CEO power and explored how powerful CEOs view investment in CSR. They found that when CEO power is lower, its increase leads to greater CSR engagement; however, as CEOs grow significantly more powerful, they become more entrenched and no longer invest as much in CSR. The study in [16] proposed a threshold beyond which the most powerful CEOs considerably reduced CSR investment.

Similarly, Harper and Sun [30] believe that when CEOs become more powerful, they may not act in the best interests of stakeholders and shareholders. Using a sample of 1574 USA-based firms over a period of several years, the authors found a significant and negative relation between CEO power and CSR activities, suggesting that firms with more powerful CEOs engaged in less CSR activity. In line with these findings, Rashid et al. [19], based on a sample of 986 Bangladeshi firms monitored annually from 2002 to 2012, found that firms with a higher level of CEO power were negatively associated with CSR disclosure. Similar results were found by Sheikh [18], based on U.S. firms listed on the S\&P 500 Index between 2003 and 2015: their findings showed a significant and negative relationship between CEO power and the four CSR dimensions of diversity, community, environment, and employee relations. Chau and Gray [40], using a sample of 273 Hong Kong firms, also found a negative and statistically significant relationship between CEO power and CSR disclosure.

Considering the above, the following hypothesis can be posed:

Hypothesis (H1). There is a negative association between CEO power and CSR disclosure.

\subsection{CEO Compensation Linked to Shareholder Return as a Moderating Variable}

According to agency theory, CEO compensation explains the manager-shareholder conflict [40] by arguing that, without supervision, managers will maximize their own wealth at the expense of that of the shareholders. To address the supervision problem, agency theory suggests incentives for CEOs, offering sufficiently high compensation for them to align their goals with those of their shareholders [41]. Borlea et al. [27] support the notion that $\mathrm{CEO}$ compensation is an effective corporate governance mechanism in mitigating conflicts between shareholders and managers: well-paid CEOs will be more likely to improve firm performance, particularly if their compensation is linked to firm performance or shareholders' returns. Furthermore, Fama and Jensen [40], focusing on agency theory, suggest that the board of directors is a control mechanism, capable of reducing information asymmetry by voluntarily disclosing relevant information (e.g., CSR issues) and aligning ownership and management interests. In this regard, CEO compensation may also affect the control and monitoring capacity of boards and, therefore, the quantity and quality of CSR information reported by firms. CSR disclosure may bring benefits in the long-term such as improved firm performance, higher competitive advantage, or greater reputation. Thus, and in line with Borlea et al. [27], well-paid CEOs, particularly those whose remuneration is linked to shareholders' returns, will be more likely to encourage CSR disclosure because it will result in a better long-term shareholder return or firm performance. In this case, more profitable firms will implement better compensation for CEOs who are paid according to this kind of remuneration structure. 
Authors including Peng [42] note that firms implement a broad variety of CEO compensation packages, and Sanders and Carpenter [43] differentiated between those in the form of cash (e.g., salary and bonus) and those including long-term contingent pay (e.g., stock options and other long-term incentive plans). These two basic forms of compensation have very different characteristics that can, in turn, affect the executives' behavior [44] For example, long-term compensation aligns the interests of executives and shareholders by offering contractual rewards for increasing shareholder wealth, equivalent to linking CEO compensation with shareholder return. Peng [42] considers that the characteristics of long-term compensation make it particularly suited to prospector strategies because it is more likely to align the interests of managers with the long-term CSR target.

Several studies have examined the effect of CEO compensation on overall CSR performance from this empirical perspective. For example, McGuire et al. [45] explored the link between CEO compensation and CSR, revealing that both salary and long-term compensation are positively related to efficient social performance. A positive relationship was also reported by Jouber [46], who suggested that the CEO pay slice is positively related to a firm's CSR practices and disclosure and found evidence that sustainability is more pronounced in certain situations such as those where greater investor protection and strict compliance with the law are found.

Conversely, authors including Deckop et al. [47] and Simerly et al. [48] found evidence of a negative relationship, revealing that pay with a short-term focus is negatively related to CSR outcomes. In the same vein, Stanwick and Stanwick [49] also found CEO compensation to be negatively related to a firm's social responsibility rating as a result of the executive director regarding CSR programs only from a financial and cost-related perspective. As observed by Russo and Fouts [50], this research topic has yielded mixed results with CEO compensation sometimes positively related to CSR, sometimes negatively and, sometimes, showing no relationship. There is, thus, no consensus in the existing literature regarding this relationship.

As far as the influence of CEO compensation on CEO power is concerned, Song and Wan [51] analyzed this relationship for CEOs of S\&P 500 companies from 1993 to 2012, and found that more powerful CEOs earned more than less powerful ones. This positive relationship could be regarded as an additional reward for CEOs with better management skills. According to this logic, higher CEO compensation reflects greater $\mathrm{CEO}$ talent and, thus, may have an impact on the CSR disclosure of firms.

Agency theory, as set out above, suggests creating incentives for CEOs to align their goals with those of their shareholders. Consequently, if a CEO's compensation is linked to shareholder return, the CEO will support CSR decisions that benefit shareholders and stakeholders. This is particularly true of powerful CEOs, since everything that relates to CSR can have a positive impact on shareholder profitability [41].

Based on the above, the following working hypothesis can be posed:

Hypothesis (H2). The association between CSR power and CSR disclosure is moderated by linking CEO compensation to shareholder return.

\section{Empirical Design \\ 4.1. Sample}

Our initial sample consisted of 13,902 international firm-year observations collected from the Thomson Reuters database from 2009 to 2018. The total number of firms in the sample was 1811 . However, financial entities and firms for which not all data variables were available were removed from the initial sample. Financial entities were excluded due to the particular accounting rules that apply to their annual financial statements, which makes it difficult to compare the financial statements of financial and non-financial firms. Thus, our final unbalanced panel data sample comprised 9182 firm-year observations. All data necessary for measuring our variables were collected from the Thomson Reuters database, which encompasses companies from different activity sectors across all countries 
in the targeted global indices (FTSE All World, Dow Jones Global, MSCI World, MSCI EMF, S\&P Global, S\&P/Citigroup) and is considered the financial industry's premier source of detailed financial statement data and profile data on public companies. Thomson Reuters' data analysts extract the data to global templates that are specific to industry groups. The templates take into consideration the variations in accounting conventions and are designed to facilitate comparisons between companies and industries within and across national boundaries. In addition to economic and financial information, the database contains many other relevant data about corporate governance and other social and environmental aspects at an international level.

Sixteen countries are represented in our international sample: Australia, Austria, Belgium, Canada, Denmark, Finland, Germany, Ireland, Japan, Netherlands, New Zealand, Norway, Sweden, Switzerland, the United Kingdom, and the United States. The country with the highest representation in our sample was the United States with $34.80 \%$, followed by Japan with $15.30 \%$, Canada with $11.50 \%$, and the United Kingdom with $11.10 \%$. In contrast, Austria was represented by only $0.4 \%$ of the sample, New Zealand by $0.5 \%$, Norway by $0.7 \%$, and Belgium by $0.9 \%$. Table 1 shows the distribution of our sample by country.

Table 1. Number of observations by country.

\begin{tabular}{cccc}
\hline Country & Observations & Percentage & Cum. \\
\hline Australia & 755 & 8.2 & 8.2 \\
Austria & 34 & 0.4 & 8.6 \\
Belgium & 81 & 0.9 & 9.5 \\
Canada & 1055 & 11.5 & 21.0 \\
Denmark & 106 & 1.2 & 22.1 \\
Finland & 137 & 1.5 & 23.6 \\
Germany & 342 & 3.7 & 27.3 \\
Ireland & 163 & 1.8 & 29.1 \\
Japan & 1405 & 15.3 & 44.4 \\
The Netherlands & 197 & 2.1 & 46.6 \\
New Zealand & 48 & 0.5 & 47.1 \\
Norway & 61 & 0.7 & 47.7 \\
Sweden & 211 & 2.3 & 50.0 \\
Switzerland & 373 & 4.1 & 54.1 \\
The United Kingdom & 1018 & 11.1 & 65.2 \\
The United States & 3196 & 34.8 & \\
\hline Total & 9182 & 100.0 & \\
\hline
\end{tabular}

The industries considered in this research are shown in Table 2, classed according to the Thomson Reuters Business Classification (TRBC) provided by Thomson Reuters. After excluding the financial sector, we considered nine of TRBC's ten industries, specifically, basic materials (representing $14.50 \%$ of the sample), consumer cyclical $(19.80 \%)$, consumer non-cyclical $(10.00 \%)$, energy $(9.20 \%)$, health care $(9.20 \%)$, industrial $(21.00 \%)$, technology $(9.00 \%)$, telecommunications services $(2.80 \%)$, and utilities $(4.50 \%)$. 
Table 2. Number of observations by activity sector.

\begin{tabular}{cccc}
\hline TRBC Economic Sector Name & Number of Observations & Percentage & Cum. \\
\hline Basic Materials & 1332 & 14.5 & 14.5 \\
Consumer Cyclical. & 1814 & 19.8 & 34.3 \\
Consumer Non-Cyclical & 915 & 10.0 & 44.2 \\
Energy & 848 & 9.2 & 53.5 \\
Health Care & 841 & 9.2 & 62.6 \\
Industrial & 1929 & 21.0 & 83.6 \\
Technology & 828 & 9.0 & 92.6 \\
Telecommunications Services & 259 & 2.8 & 95.5 \\
Utilities & 416 & 4.5 & 100.0 \\
\hline Total & 9182 & 100.0 & \\
\hline
\end{tabular}

\subsection{Research Variables}

\subsubsection{Dependent Variable}

The dependent variable used in this research was CSR reporting, denoted by CSR_DISC. This variable was measured as the ratio between the aggregation of 112 items concerning environmental and social issues and the total number of items analyzed (112). If the item considered is disclosed by the firm, it takes the value 1; otherwise, it takes 0 . Our CSR measure is multidimensional, in line with Carroll [52], who suggests that CSR is accepted as a multidimensional construct focused on various environmental and social aspects including human rights, product responsibility, and emissions. All the items included in our analysis for calculating our CSR disclosure variable are shown in Table 3. This variable ranges between 0 and 1 . Accordingly, a firm with 0 points discloses no CSR information, a firm with 0.1-0.5 points makes a moderate disclosure of CSR information, a firm with 0.6-0.9 points makes a relevant disclosure of CSR information, and a firm with 1 point makes a complete disclosure of CSR information. Thus, our aim was to analyze the CSR information reported by firms. Our approach to measuring CSR disclosure is consistent with past research [53-55].

\subsubsection{Independent Variables}

Our independent variable was CEO power, labelled as CEO_POW. To construct this variable, we aggregated three dummy variables: (1) CEO duality, which takes the value 1 if the same person serves simultaneously as $\mathrm{CEO}$ and chairman of the board and 0 otherwise; (2) CEO tenure, which takes the value 1 if CEO tenure is above the sample median and 0 otherwise; and (3) CEO board membership, which takes the value 1 if the CEO serves as a board member, but not as chair of the board, and 0 otherwise. This variable will, therefore, vary between 1 and 3. Its construction is in line with past research [56]. The existing literature on CEO power considers CEO duality to be a strong source of CEO power [57]. Furthermore, Finkelstein [10] suggests that $C E O$ tenure increases the influence of the CEO over the board and its performance and, therefore, CEO power increases. Tenure is an indicator of a CEO's knowledge of the policies and processes in the firm and, once appointed, a CEO is in a position to enhance their own power. Tien et al. [58] also support the notion that one of the key functions of a board is to monitor and control top management, and the joint CEO-Director role (where the CEO serves on the board of directors) can weaken board control and, thus, increase CEO power, as suggested by agency theory.

Our moderating variable is the linking of CEO compensation to total shareholder return, denoted as CEO_COMP_SHARHOL and measured as a dummy variable, which takes the value 1 if the CEO's compensation is linked to the total shareholder return and 0 otherwise. We will construct the interaction variable CEO_COMP_SHARHOL $\times$ CEO_POW in order to analyze whether CEO compensation linked to the total shareholder return moderates the relationship between CEO power and CSR disclosure. 
Table 3. Corporate social responsibility disclosure items.

\begin{tabular}{|c|c|c|c|c|c|c|}
\hline Resource Use & Emissions & Innovation & Workforce & Human Rights & Community & $\begin{array}{c}\text { Product } \\
\text { Responsibility }\end{array}$ \\
\hline $\begin{array}{c}\text { Resource } \\
\text { reduction policy }\end{array}$ & Policy emissions & $\begin{array}{l}\text { Environmental } \\
\text { products }\end{array}$ & $\begin{array}{l}\text { Health and safety } \\
\text { policy }\end{array}$ & $\begin{array}{l}\text { Human rights } \\
\text { policy }\end{array}$ & $\begin{array}{c}\text { Employee } \\
\text { engagement volunteer } \\
\text { work }\end{array}$ & $\begin{array}{l}\text { Policy customer } \\
\text { health and safety }\end{array}$ \\
\hline $\begin{array}{l}\text { Policy water } \\
\text { efficiency }\end{array}$ & Targets emissions & $\begin{array}{l}\text { Eco-design } \\
\text { products }\end{array}$ & $\begin{array}{l}\text { Policy employee } \\
\text { health and safety }\end{array}$ & $\begin{array}{l}\text { Policy freedom of } \\
\text { association }\end{array}$ & $\begin{array}{l}\text { Corporate } \\
\text { responsibility awards }\end{array}$ & $\begin{array}{l}\text { Policy data } \\
\text { privacy }\end{array}$ \\
\hline $\begin{array}{l}\text { Policy energy } \\
\text { efficiency }\end{array}$ & $\begin{array}{l}\text { Biodiversity impact } \\
\text { reduction }\end{array}$ & Noise reduction & $\begin{array}{l}\text { Policy supply chain } \\
\text { health and safety }\end{array}$ & Policy child labor & $\begin{array}{c}\text { Product sales at } \\
\text { discount to emerging } \\
\text { markets }\end{array}$ & $\begin{array}{l}\text { Policy } \\
\text { responsible } \\
\text { marketing }\end{array}$ \\
\hline $\begin{array}{c}\text { Policy sustainable } \\
\text { packaging }\end{array}$ & Emissions trading & Hybrid vehicles & $\begin{array}{c}\text { Training and } \\
\text { development policy }\end{array}$ & $\begin{array}{c}\text { Policy forced } \\
\text { labor }\end{array}$ & $\begin{array}{l}\text { Diseases of the } \\
\text { developing world }\end{array}$ & Policy fair trade \\
\hline $\begin{array}{c}\text { Policy } \\
\text { environment } \\
\text { supply chain }\end{array}$ & $\begin{array}{l}\text { Climate change } \\
\text { commercial risks } \\
\text { opportunities }\end{array}$ & $\begin{array}{l}\text { Environmental } \\
\text { assets under MGT }\end{array}$ & Policy skills training & $\begin{array}{l}\text { Policy human } \\
\text { rights }\end{array}$ & $\begin{array}{l}\text { Bribery corruption } \\
\text { and fraud } \\
\text { controversies }\end{array}$ & $\begin{array}{l}\text { Product } \\
\text { responsibility } \\
\text { monitor }\end{array}$ \\
\hline $\begin{array}{l}\text { Resource } \\
\text { reduction targets }\end{array}$ & $\begin{array}{l}\text { Nox and Sox } \\
\text { emissions reduction }\end{array}$ & Equator principles & $\begin{array}{l}\text { Policy career } \\
\text { development }\end{array}$ & $\begin{array}{c}\text { Fundamental } \\
\text { human rights ILO } \\
\text { UN }\end{array}$ & $\begin{array}{l}\text { Crisis management } \\
\text { systems }\end{array}$ & $\begin{array}{l}\text { Quality mgt } \\
\text { systems }\end{array}$ \\
\hline $\begin{array}{l}\text { Environment } \\
\text { management } \\
\text { team }\end{array}$ & $\begin{array}{l}\text { VOC or particulate } \\
\text { matter emissions }\end{array}$ & $\begin{array}{l}\text { Equator principles } \\
\text { or environmental } \\
\text { projects }\end{array}$ & $\begin{array}{l}\text { Policy diversity and } \\
\text { opportunity }\end{array}$ & $\begin{array}{l}\text { Human rights } \\
\text { contractor }\end{array}$ & $\begin{array}{l}\text { Anti-competition } \\
\text { controversies }\end{array}$ & ISO 9000 \\
\hline $\begin{array}{l}\text { Environment } \\
\text { management } \\
\text { training }\end{array}$ & $\begin{array}{l}\text { VOC emissions } \\
\text { reduction }\end{array}$ & $\begin{array}{l}\text { Environmental } \\
\text { project financing }\end{array}$ & $\begin{array}{l}\text { Employees health and } \\
\text { safety team }\end{array}$ & $\begin{array}{l}\text { Ethical trading } \\
\text { initiative ETI }\end{array}$ & & $\begin{array}{l}\text { Six sigma and } \\
\text { quality mgt } \\
\text { systems }\end{array}$ \\
\hline $\begin{array}{l}\text { Environmental } \\
\text { materials } \\
\text { sourcing }\end{array}$ & $\begin{array}{l}\text { Particulate matter } \\
\text { emission reduction }\end{array}$ & Nuclear & $\begin{array}{l}\text { Health and safety } \\
\text { training }\end{array}$ & $\begin{array}{c}\text { Human rights } \\
\text { breaches } \\
\text { contractor }\end{array}$ & & $\begin{array}{l}\text { Product access } \\
\text { low price }\end{array}$ \\
\hline $\begin{array}{l}\text { Toxic chemicals } \\
\text { reduction }\end{array}$ & Waste reduction total & Labeled wood & $\begin{array}{l}\text { Supply chain health } \\
\text { and safety training }\end{array}$ & & & $\begin{array}{l}\text { Healthy food or } \\
\text { products }\end{array}$ \\
\hline $\begin{array}{l}\text { Renewable } \\
\text { energy use }\end{array}$ & e-Waste reduction & $\begin{array}{l}\text { Organic products } \\
\text { initiatives }\end{array}$ & $\begin{array}{c}\text { Employees health and } \\
\text { safety OHSAS } 18001\end{array}$ & & & $\begin{array}{l}\text { Embryonic stem } \\
\text { cell research }\end{array}$ \\
\hline Green buildings & $\begin{array}{l}\text { Environmental } \\
\text { restoration initiatives }\end{array}$ & $\begin{array}{c}\text { Product impact } \\
\text { minimization }\end{array}$ & $\begin{array}{c}\text { Flexible working } \\
\text { hours }\end{array}$ & & & $\begin{array}{l}\text { Retailing } \\
\text { responsibility }\end{array}$ \\
\hline $\begin{array}{l}\text { Environmental } \\
\text { supply chain } \\
\text { management }\end{array}$ & $\begin{array}{l}\text { Staff transportation } \\
\text { impact reduction }\end{array}$ & $\begin{array}{l}\text { Take-back and } \\
\text { recycling initiatives }\end{array}$ & Day care services & & & Alcohol \\
\hline $\begin{array}{l}\text { Environmental } \\
\text { supply chain } \\
\text { monitoring }\end{array}$ & $\begin{array}{l}\text { Environmental } \\
\text { expenditures } \\
\text { investment }\end{array}$ & $\begin{array}{l}\text { Product } \\
\text { environmental } \\
\text { responsible use }\end{array}$ & Employee fatalities & & & Gambling \\
\hline $\begin{array}{l}\text { Env supply chain } \\
\text { partnership } \\
\text { termination }\end{array}$ & & GMO products & HIV / AIDS program & & & Tobacco \\
\hline $\begin{array}{c}\text { Land } \\
\text { environmental } \\
\text { impact reduction }\end{array}$ & & $\begin{array}{l}\text { Agrochemical } \\
\text { products }\end{array}$ & Internal promotion & & & Armaments \\
\hline \multirow[t]{7}{*}{$\begin{array}{c}\text { Environmental } \\
\text { controversies }\end{array}$} & & $\begin{array}{l}\text { Agrochemical } 5 \% \\
\text { revenue }\end{array}$ & Management training & & & Obesity risk \\
\hline & & $\begin{array}{l}\text { Animal testing in } \\
\text { the last } 12 \mathrm{fy}\end{array}$ & Supplier ESG training & & & Cluster bombs \\
\hline & & $\begin{array}{l}\text { Animal testing } \\
\text { cosmetics }\end{array}$ & $\begin{array}{l}\text { Wages working } \\
\text { condition } \\
\text { controversies }\end{array}$ & & & $\begin{array}{l}\text { Anti-personnel } \\
\text { landmines }\end{array}$ \\
\hline & & $\begin{array}{l}\text { Animal testing } \\
\text { reduction }\end{array}$ & & & & $\begin{array}{l}\text { Consumer } \\
\text { complaints }\end{array}$ \\
\hline & & $\begin{array}{l}\text { Renewable clean } \\
\text { energy products }\end{array}$ & & & & $\begin{array}{l}\text { Customer } \\
\text { controversies }\end{array}$ \\
\hline & & Water technologies & & & & $\begin{array}{c}\text { Responsible } \\
\text { marketing } \\
\text { controversies }\end{array}$ \\
\hline & & $\begin{array}{l}\text { Sustainable } \\
\text { building products }\end{array}$ & & & & Product recall \\
\hline
\end{tabular}

\subsubsection{Control Variables}

Several factors may potentially affect CSR disclosure. The first control variable used is firm size (SIZE), measured as the log of total assets. Past research [59] shows that large firms tend to disclose more CSR information because they are under greater pressure 
from stakeholders than small firms. Return on assets (ROA) and leverage (LEVERAGE) were also controlled in this research. ROA is calculated as the operating income before interest and taxes over total assets, and LEVERAGE as the ratio between debt and total assets. According to previous research [60], more profitable firms (in terms of ROA) are more likely to report CSR issues because these may have a positive impact on the firm's long-term profit. However, there is no conclusive evidence about the effect of leverage on CSR disclosure. In this regard, Dyduch and Krasodomska [61] present studies that show a positive relationship between leverage and CSR reporting and those showing a negative one. Regarding board composition, we have also considered the presence of female directors (WOMEN_DIRECT) and outsiders (OUTSIDERS) on boards. WOMEN_DIRECT is calculated as the ratio between the number of female directors on a board and the total number of directors on the board. As claimed by Pucheta-Martínez and GallegoÁlvarez [62], board gender diversity is positively associated with CSR disclosure because female directors tend to be more oriented toward social and environmental issues and are more open-minded than male directors. OUTSIDERS is measured as the ratio between the total number of external directors on a board and the total number of directors on the board. Previous studies $[63,64]$ are inconclusive as to whether board independence or outsiders affect CSR disclosure, and shows both a positive and a negative effect. The lack of capability of independent directors on CSR issues would support a negative association between independent members and CSR disclosure, while their interest in safeguarding the interests of shareholders, particularly minority shareholders, may be a positive one. The presence of a CSR committee has also been controlled. This variable is denoted by CSR_COMMT and is measured as a dummy variable that takes the value 1 if the firm has a CSR committee and 0 otherwise. A positive relationship is expected between the existence of a CSR committee and CSR disclosure since this committee is directly involved with CSR issues such as reporting [50]. Board size, labelled as BODSIZE, is also considered and is calculated as the total number of directors on a board. It is expected that board size will have a positive impact on CSR disclosure, in line with Pucheta-Martínez and Gallego-Álvarez [62]. CSR reporting requires additional work and diverse expertise as well as mechanisms to control and advise boards regarding these issues, which may be possible with bigger boards. We also controlled for the sector in which firms operate. The sector is calculated as a dummy variable that will be coded as 1 if the firm operates in the sector considered and 0 otherwise. This variable is denoted as SECTOR and we considered nine sectors: basic materials, consumer cyclicals, consumer non-cyclicals, energy, health care, industrials, technology, telecommunications services, and utilities. Martín-de Castro et al. [64] found that firms operating in more sensitive industries such as chemical, mining industries or oil tended to report more CSR information in order to preserve their reputation and legitimacy in the face of public scrutiny by stakeholders and government. Table 4 shows a summary of all the variables used in this research: dependent, independent, and control variables.

\subsection{Economic Model}

Our hypotheses were checked by running the following model:

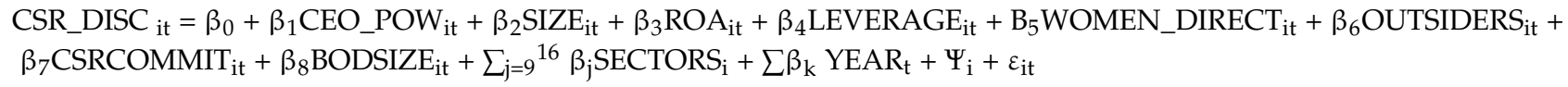

where firm-specific and firm-fixed effects (unobservable heterogeneity) are represented by $\Psi_{\mathrm{i}}$. These effects are controlled because they can potentially impact CSR disclosure. In this way, we controlled for the unobservable features of firms that oscillate between individuals and do not change over time. The error terms are represented by $\varepsilon_{i t}$. 
Table 4. Variables description.

\begin{tabular}{|c|c|c|}
\hline Variables & Description & Expected Sign \\
\hline \multicolumn{3}{|l|}{ Dependent variable } \\
\hline CSR_DISC & $\begin{array}{l}\text { Corporate social responsibility disclosure is the ratio between the aggregation of } 112 \\
\text { items concerning social and environmental issues and the total items (112) }\end{array}$ & \\
\hline \multicolumn{3}{|l|}{ Independent variable } \\
\hline CEO_POW & $\begin{array}{l}\text { CEO power is the aggregation of tree dummies variables: (1) CEO duality, which is a } \\
\text { dummy variable that takes the value } 1 \text { if the same person serves simultaneously as CEO } \\
\text { and chairman of the board and } 0 \text {, otherwise, (2) CEO tenure, which is a dummy variable } \\
\text { that takes the value } 1 \text { if CEO tenure is above the sample median and } 0 \text {, otherwise and (3) } \\
\text { CEO board member, which is a dummy variable that takes the value } 1 \text { if the CEO serves } \\
\text { as a board member, but not as chair of the board and } 0 \text {, otherwise }\end{array}$ & - \\
\hline \multicolumn{3}{|l|}{ Moderating variable } \\
\hline CEO_COMP_SHARHOL & $\begin{array}{l}\text { CEO compensation linked to shareholder return is a dummy variable, which takes the } \\
\text { value } 1 \text { if the CEO's compensation is linked to the total shareholder return } \\
\text { (TSR) and 0, otherwise }\end{array}$ & + \\
\hline \multicolumn{3}{|l|}{ Control variables } \\
\hline SIZE & Firm size is the log of total assets & + \\
\hline ROA & Return on assets is the operate income before interests and taxes over total assets & + \\
\hline LEVERAGE & Leverage is the debt over total assets & $+/-$ \\
\hline WOMEN_DIRECT & $\begin{array}{l}\text { The proportion of women directors on boards is calculated as the ratio between the total } \\
\text { number of women directors on boards and the total number of directors on boards }\end{array}$ & + \\
\hline OUTSIDERS & $\begin{array}{l}\text { The proportion of external directors on boards is calculated as the ratio between the total } \\
\text { number of external directors on boards and the total number of directors on boards }\end{array}$ & $+/-$ \\
\hline CSR_COMMT & $\begin{array}{c}\text { The presence of a corporate social responsibility committee in firms is a dummy variable } \\
\text { that takes the value } 1 \text { if the firm has a corporate social } \\
\text { responsibility committee and 0, otherwise }\end{array}$ & + \\
\hline BODSIZE & Board size is the total number of directors on boards & + \\
\hline BASIC MATERIALS & Dummy variable: $1=$ Basic Materials; $0=$ Otherwise & $+/-$ \\
\hline CONSUMER CYCLICAL & Dummy variable: $1=$ Consumer Cyclical; $0=$ Otherwise & $+/-$ \\
\hline CONSUMER NON-CYCLICAL & Dummy variable: $1=$ Consumer Non-Cyclical; $0=$ Otherwise & $+/-$ \\
\hline ENERGY & Dummy variable: $1=$ Energy; $0=$ Otherwise & $+/-$ \\
\hline HEALTH CARE & Dummy variable: $1=$ Healthcare; $0=$ Otherwise & $+/-$ \\
\hline INDUSTRIALS & Dummy variable: $1=$ Industrial; $0=$ Otherwise & $+/-$ \\
\hline TECHNOLOGY & Dummy variable: $1=$ Technology; $0=$ Otherwise & $+/-$ \\
\hline $\begin{array}{l}\text { TELECOMMUNICATION } \\
\text { SERVICES }\end{array}$ & Dummy variable: $1=$ Telecommunication Services; 0 = Otherwise & $+/-$ \\
\hline UTILITIES & Dummy variable: $1=$ Utilities; $0=$ Otherwise & $+/-$ \\
\hline
\end{tabular}

Our model was estimated using the generalized method of moments (GMM) estimator (Arellano and Bond [65]), which offers higher consistency and efficiency than other estimators because it controls for unobservable heterogeneity $\left(\Psi_{\mathrm{i}}\right)$. Additionally, endogeneity and estimation bias are also controlled by the GMM estimator, which additionally provides us with the Wald $\chi^{2}$ test, the Arellano-Bond tests-AR(1) and AR(2) - and the Hansen test. The Wald $\chi^{2}$ test assesses the fitness of our model. The Arellano-Bond test AR(2) assesses whether a second-order serial correlation exists in the first difference. The rejection of the null hypothesis of 'no serial correlations' confirms the non-existence of a second-order serial correlation. Finally, the Hansen test of over-identifying restrictions assesses whether the instruments used in the model are suitable.

\section{Results}

\subsection{Descriptive Statistics and Correlations}

The descriptive statistics and correlations are provided in Tables 5 and 6, respectively. 
Focusing on the descriptive statistics, firms in our international sample disclosed, on average, 0.25 CSR information out of a possible maximum of 1 . Our CSR score was placed between 0.1 and 0.5 and, therefore, gave a moderate level of CSR disclosure for firms in our sample, according to the classification given in the dependent variable description. CEO power can vary between 1 and 3 and was in this research an average of 1.31, and 50.07\% of firms in our sample linked CEO compensation to shareholder return. The SIZE, ROA, and LEVERAGE of firms were 9.60, 6.44\%, and $62.41 \%$, respectively. Regarding board composition in firms in our sample, $12.41 \%$ of board members were women and $74.14 \%$ were outsiders; $52.78 \%$ of firms had a CSR committee, and the average number of board members was 10.40. In the sample section, the representation of all sectors analyzed in this research have been discussed.

Table 5. Descriptive analysis.

\begin{tabular}{cccc}
\hline Variable & Obs. & Mean & Std. Dev. \\
\hline CSR_DISC & 9182 & 0.252 & 0.159 \\
CEO_POW & 9182 & 1.316 & 0.578 \\
CEO_COMP_SHARHOL & 9182 & 50.076 & 50.003 \\
SIZE & 9182 & 9.605 & 1.422 \\
ROA & 9182 & 6.446 & 7.630 \\
LEVERAGE & 9182 & 62.417 & 50.661 \\
WOMEN_DIRECT & 9182 & 12.412 & 11.001 \\
OUTSIDERS & 9182 & 74.144 & 25.914 \\
CSR_COMMT & 9182 & 52.788 & 49.924 \\
BODSIZE & 9182 & 10.405 & 3.252 \\
BASIC MATERIALS & 9182 & 14.500 & 35.219 \\
CONSUMER CYCLICAL & 9182 & 19.800 & 39.818 \\
CONSUMER NON-CYCLICAL & 9182 & 10.000 & 29.955 \\
ENERGY & 9182 & 9.200 & 28.954 \\
HEALTH CARE & 9182 & 9.200 & 28.846 \\
INDUSTRIALS & 9182 & 21.000 & 40.739 \\
TECHNOLOGY & 9182 & 9.000 & 28.645 \\
TELECOMMNICATION SERVICES & 9182 & 2.800 & 16.557 \\
UTILITIES & 9182 & 4.500 & 20.798
\end{tabular}

Mean and standard deviation, CSR_DISC (corporate social responsibility disclosure) is the ratio between the aggregation of 112 items concerning social and environmental issues and the total items (112); CEO_POW (CEO power) is the aggregation of tree dummies variables: (1) CEO duality, which is a dummy variable that takes the value 1 if the same person serves simultaneously as CEO and chairman of the board and 0, otherwise, (2) CEO tenure, which is a dummy variable that takes the value 1 if $\mathrm{CEO}$ tenure is above the sample median and 0 , otherwise and (3) CEO board member, which is a dummy variable that takes the value 1 if the CEO serves as a board member, but not as chair of the board and 0, otherwise; CEO_COMP_SHARHOL (CEO compensation linked to shareholder return) is a dummy variable, which takes the value 1 if the CEO's compensation is linked to total shareholder return (TSR) and 0, otherwise; SIZE (Firm size) is the log of total assets; ROA (Return on assets) is the operate income before interests and taxes over total assets; LEV is the debt over total assets; WOMEN_DIRECT (Women directors on boards) is the proportion of women directors on boards = Total number of women directors on boards/Total number of directors on boards; OUTSIDERS (outsiders on boards) is measured as the proportion of outside directors on boards; CSR_COMMT (The presence of an corporate social responsibility committee in firms) is a dummy variable that takes the value 1 if the firm has a CSR Committee and 0, otherwise; BODSIZE (Board size) is the number of directors on board; Basic Materials if the company operates in Basic Materials sector and 0, otherwise; Consumer Cyclical if the company operates in Consumer Cyclical sector and 0, otherwise; Consumer Non-Cyclical if the company operates in Consumer Non-Cyclical sector and 0, otherwise; Energy if the company operates in Energy sector and 0, otherwise; Health Care if the company operates in Health Care sector and 0, otherwise; Industrials if the company operates in Industrials sector and 0, otherwise; Technology if the company operates in Technology sector and 0, otherwise; Telecommunication Services if the company operates in Telecommunication Services sector and 0, otherwise; Utilities if the company operates in Utilities sector and 0, otherwise. 
Table 6. Correlation matrix.

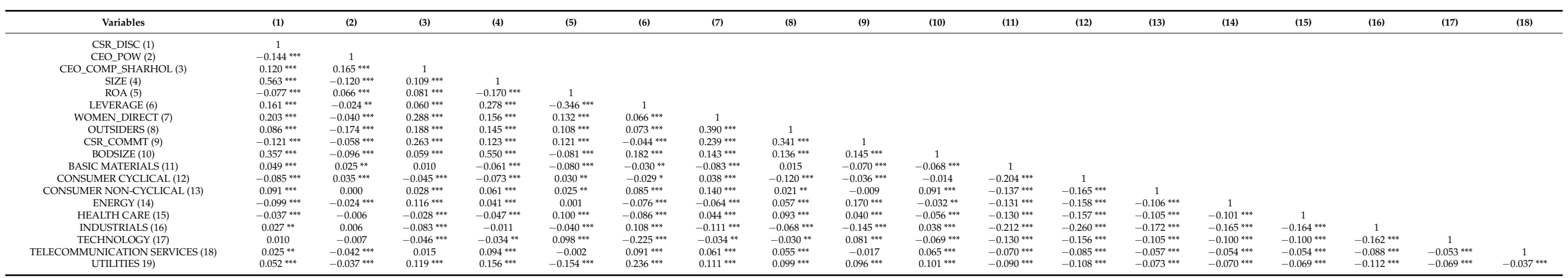

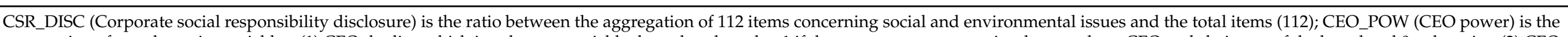

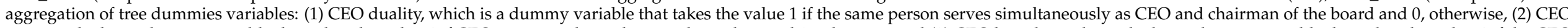

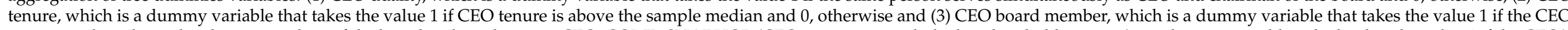

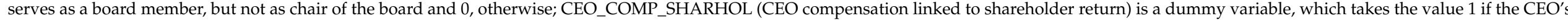

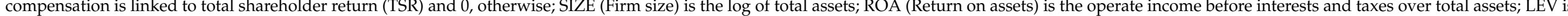

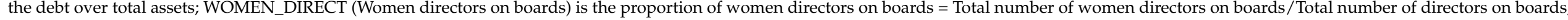

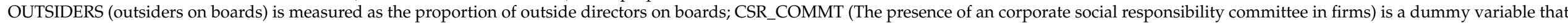

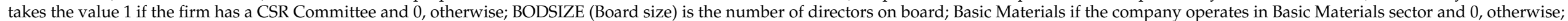

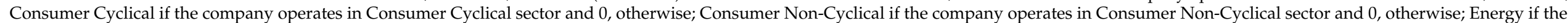

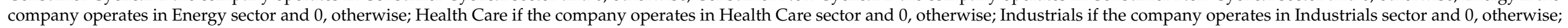

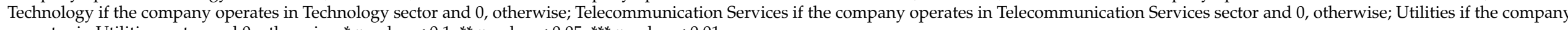
operates in Utilities sector and 0 , otherwise. ${ }^{*} p$-value $<0.1{ }^{* *} p$-value $<0.05,{ }^{* * *} p$-value $<0.01$. 
As indicated, in Table 6, we exhibit all the correlation pairs in order to check for multicollinearity; none of the pairs provided a figure higher than 0.8 , the figure shown in past research to be critical [66] in identifying multicollinearity problems.

\subsection{Multivariate Analysis}

In Table 7, we present Model 1, where the impact of CEO power on CSR reporting is examined. The CEO_POW variable exhibits a positive sign, contrary to our predictions. Thus, the first hypothesis must be rejected. This finding suggests that powerful CEOs tend to support decisions to divulge greater CSR information and runs contrary to past research $[18,19,30]$, which reveals that CEO power has a negative effect on CSR reporting. Thus, our evidence shows that CEOs with more power will be less concerned regarding the cost of CSR activities and their own needs and interests and more oriented toward disclosing CSR information and focusing on stakeholder needs. It may be that the CEOs' interests and returns are associated with these CSR activities and, therefore, they are interested in showing their engagement with social and environmental issues. Thus, CEOs can also signal their commitment to stakeholders' needs and interests. It can be a way for CEOs to mitigate the pressure of powerful stakeholders as well as avoiding or reducing their supervision, or to improve CEO compensation or tenure. Furthermore, powerful CEOs may engage in and disclose CSR activities to maintain relationships with relevant and powerful stakeholders and to maintain human capital against short-term investors and manage the risk derived from financial and investment strategies. Concerning the control variables, only the percentage of women directors on boards had a negative impact on CSR reporting. The remaining control variables were not significant.

The findings may be also relevant from an international perspective because we used a sample of sixteen countries with varied cultural, political, and corporate governance, among other differences. In this regard, our findings revealed that powerful CEOs become pertinent figures in the implementation and functioning of CSR strategies by encouraging CSR disclosure in non-financial firms across the globe. CSR reporting is, thus, not independent from CEO power in firms, power acquired in countries with relevant differences. Thus, this power may vary among countries. Stakeholders from countries other than those used in our research may exert pressure on firms in these countries to hire powerful CEOs because they are more likely to disclose CSR information.

In Table 7, Model 2, we explore the moderating role played by linking CEO compensation to shareholder return on CEO power and CSR reporting. To analyze this relationship, we constructed the interaction CEO_COMP_SHARHOL $\times$ CEO_POW. As appreciated, this variable exhibited a positive sign and was statistically significant. This evidence shows that linking CEOs' compensation to shareholder return positively moderates the positive association between CEO power and CSR disclosure, that is, it reinforces the positive impact of CEO power on CSR reporting. Thus, if CSR disclosure maximizes the shareholders' return, powerful CEOs whose compensation is linked to shareholder return will be more likely to increase CSR disclosure. Higher disclosure and transparency of CSR information may be beneficial for stakeholders, and particularly shareholders, who can see an improvement in their returns. Powerful CEOs with pay linked to the shareholder return may have an interest in supporting a board decision in favor of greater reporting of CSR issues since this may lead to better compensation for them. Given their influence over boards, CEOs may persuade many board members to align with them on decisions oriented toward CSR. In this model, as in Model 1, the only significant control variable was female directors, which showed a negative sign. The remaining variables were insignificant. In line with the discussion above, the evidence of the positive moderating role played by CEO compensation linked to shareholder return on CEO power and CSR disclosure also merits discussion from an international perspective. Compensation packages for CEOs differ, depending on the country in which the firms operate. The compensation of CEOs by stock options allows them the right-with no obligation - to buy a certain number of company shares in the future at today's market price, thus enabling CEOs to benefit if the 
company's stock price rises, but not lose out if it falls. Packages linked to shareholder return are associated with the rise or fall of a firm's stock price, resulting in a higher or lower shareholder return. A good CSR performance can benefit firms in the long term because it can positively affect stock prices and, consequently, shareholder return. Although such pay packages are used in most countries, they are more common in some than others, that is, they are not equally applied in all countries. However, our findings show that CEOs paid through mechanisms linked to shareholder return, irrespective of the extent to which these mechanisms are used, have a positive impact on the positive association between CEO power and CSR reporting. Thus, this type of payment structure for CEOs is a relevant factor to be considered, particularly for powerful CEOs. Strong stakeholders around the world interested in demanding more transparency and greater disclosure of CSR information should also consider how powerful CEOs in firms are paid, given the positive impact of such mechanisms on CSR disclosure.

Table 7. Multivariate analysis results of the Generalized Method of Moments.

\begin{tabular}{|c|c|c|}
\hline Variables & $\begin{array}{l}\text { MODEL } 1 \\
\text { Coef. }\end{array}$ & $\begin{array}{l}\text { MODEL } 2 \\
\text { Coef. }\end{array}$ \\
\hline CSR_SCORE $\left(t_{-1}\right)$ & $1.207^{* * *}$ & $1.132 * * *$ \\
\hline CEO_POW & $0.047^{* * *}$ & $0.136 * *$ \\
\hline SIZE & 0.041 & -0.023 \\
\hline $\mathrm{ROA}$ & 0.007 & -0.001 \\
\hline LEVERAGE & 0.000 & -0.001 \\
\hline WOMEN_DIRECT & $-0.012 * *$ & $-0.011 *$ \\
\hline OUTSIDERS & 0.002 & 0.001 \\
\hline CSR_COMMT & 0.022 & -0.021 \\
\hline BODSIZE & -0.005 & 0.012 \\
\hline BASIC MATERIALS & -0.068 & 0.085 \\
\hline CONSUMER CYCLICAL & -0.163 & 0.091 \\
\hline CONSUMER NON-CYCLICAL & -0.045 & 0.107 \\
\hline ENERGY & -0.035 & -0.030 \\
\hline HEALTH CARE & -0.092 & 0.164 \\
\hline INDUSTRIALS & -0.057 & 0.026 \\
\hline TECHNOLOGY & -0.129 & 0.300 \\
\hline TELECOMMUNICATION SERVICES & -1.063 & -0.879 \\
\hline CEO_COMP_SHARHOL & & $-0.423 *$ \\
\hline CEO_COMP_SHARHOL $\times$ CEO_POW & & $0.264 *$ \\
\hline Year effects & Yes & Yes \\
\hline Wald $\chi^{2}$ test & $1922.4^{* * *}$ & $3015.02 * * *$ \\
\hline Arellano-Bond test AR(1) $(z, p>|z|)$ & $-1.89(0.059)$ & $-1.96(0.051)$ \\
\hline Arellano-Bond test $\operatorname{AR}(2)(z, p>|z|)$ & $1.28(0.200)$ & $1.57(0.115)$ \\
\hline Hansen test (chi-square, $\left.p>\left|c^{2} i^{2}\right|\right)$ & $10.87(0.285)$ & $11.61(0.236)$ \\
\hline
\end{tabular}

CSR_DISC (Corporate social responsibility disclosure) is the ratio between the aggregation of 112 items concerning social and environmental issues and the total items (112); CEO_POW (CEO power) is the aggregation of tree dummies variables: (1) CEO duality, which is a dummy variable that takes the value 1 if the same person serves simultaneously as CEO and chairman of the board and 0, otherwise, (2) CEO tenure, which is a dummy variable that takes the value 1 if CEO tenure is above the sample median and 0, otherwise and (3) CEO board member, which is a dummy variable that takes the value 1 if the CEO serves as a board member, but not as chair of the board and 0, otherwise; CEO_COMP_SHARHOL (CEO compensation linked to shareholder return) is a dummy variable, which takes the value 1 if the CEO's compensation is linked to total shareholder return (TSR) and 0 , otherwise; SIZE (Firm size) is the log of total assets; ROA (Return on assets) is the operate income before interests and taxes over total assets; LEV is the debt over total assets; WOMEN_DIRECT (Women directors on boards) is the proportion of women directors on boards = Total number of women directors on boards/Total number of directors on boards; OUTSIDERS (outsiders on boards) is measured as the proportion of outside directors on boards; CSR_COMMT (The presence of an corporate social responsibility committee in firms) is a dummy variable that takes the value 1 if the firm has a CSR Committee and 0, otherwise; BODSIZE (Board size) is the number of directors on board; Basic Materials if the company operates in Basic Materials sector and 0, otherwise; Consumer Cyclical if the company operates in Consumer Cyclical sector and 0, otherwise; Consumer Non-Cyclical if the company operates in Consumer Non-Cyclical sector and 0, otherwise; Energy if the company operates in Energy sector and 0, otherwise; Health Care if the company operates in Health Care sector and 0, otherwise; Industrials if the company operates in Industrials sector and 0, otherwise; Technology if the company operates in Technology sector and 0, otherwise; Telecommunication Services if the company operates in Telecommunication Services sector and 0 , otherwise; Utilities if the company operates in Utilities sector and 0, otherwise. ${ }^{*} p$-value $<0.1$, ** $p$-value $<0.05,{ }^{* * *} p$-value $<0.01$. 


\section{Conclusions}

This paper examined how powerful CEOs in firms affect CSR disclosure. Additionally, it analyzed the moderating role of linking CEOs' compensation to shareholder return on the relationship between CEO power and CSR reporting.

The findings show that CEO power, unexpectedly, encourages a greater disclosure of CSR information. Powerful CEOs may be involved in CSR issues such as greater disclosure, in contrast to earlier evidence, as a sign of their commitment to the demands and interests of all stakeholders. It is a means of maintaining good relationships with powerful stakeholders and avoiding pressure from them. Moreover, our evidence also reports that linking CEOs' compensation to shareholder returns has a positive influence on the positive association between CEO power and CSR disclosure. If CSR disclosure is positively associated with shareholder return, powerful CEOs who are paid with compensation linked to shareholder return will be more likely to align their decisions with stakeholder demands and interests and will support board decisions in favor of CSR reporting. One of the most relevant lessons we have learnt in this paper is the need for more research in this area given the inconclusive evidence in the existing literature. Our findings about the positive effect of CEO power on CSR disclosure-using an international sample of firms-are in contrast to past research conducted in individual countries, which showed a negative association between CEO power and CSR reporting. As far as we know, no previous studies on this topic have focused on a sample of international firms and, therefore, we have no reference for comparing our results from an international perspective, but only from national perspectives. We can extend this discussion to the moderating role performed by linking CEOs' compensation to shareholder return on the relationship between CEO power and CSR disclosure because, to the best of our knowledge, there is no preceding evidence of the positive effect of this relationship either. Another lesson learnt in this paper is that the debate on how CEO power affects CSR disclosure, from both agency and stakeholder perspectives, should continue. Our evidence is not consistent with the theoretical reasonings suggested by agency or stakeholder approaches, suggesting a need to rethink the theoretical backgrounds of these two views with reference to the core topic of this research or to propose the use of other approaches more consistent with our evidence.

Some implications can be derived from our results. First, our conclusions regarding the positive effect of CEO power on CSR disclosure may be relevant for policy-makers when regulating the role of powerful CEOs. In the majority of countries, regulatory bodies tend to encourage, for instance, the separation of the CEO's role from that of the chair of the board (an indicator of CEO power) and, in some cases, this separation is compulsory by law. Past research also provides evidence in this regard. However, our evidence seems to indicate that CEO duality is not always as harmful as most norms and corporate governance codes suggest, given its positive impact on CSR reporting. Second, from an academic and managerial point of view, our findings suggest, in line with earlier evidence, that the implementation of management compensation programs linked to shareholder return may align the interests of stakeholders—specifically shareholders-and managers (i.e., CEOs) and avoid managerial mischief. This thesis is supported by our findings, which show that powerful CEOS whose compensation is linked to shareholder returns are likely to disclose more CSR information, particularly if CSR reporting is positively associated with shareholder return. Our findings reinforce the theoretical and empirical rationalities suggested by agency theory regarding the alignment role of a managerial compensation plan linked to shareholder returns. Finally, our results may also have implications for stakeholders, shareholders, and firms. Stakeholders may be more interested in those firms that implement compensation plans for managers-including powerful CEOs-linked to shareholder return, if CSR activity increases shareholder return, because this may, in turn, increase CSR disclosure. Shareholders may also benefit from these strategic decisions in the form of improved returns; they can also demonstrate to society and stakeholders their commitment to social and environmental matters. 
However, this research also presents some caveats. First, our sample included only 16 countries across the world; it is possible that the inclusion of more countries would have enriched the findings. The decision not to use a more extended sample including different contexts was, however, due to a lack of data for other countries. Second, it may be that theoretical and empirical factors affecting CSR disclosure have been disregarded in this analysis. Finally, other theoretical perspectives could have been used in the theoretical framework adopted in this research, but we have selected those that better fit the aim of this paper.

Our findings suggest a number of lines for future research. Our analysis focused on non-financial firms. It would be interesting, however, to investigate the following two questions: (1) whether CEO power in financial firms affects CSR disclosure, and (2) whether powerful CEOs in financial firms paid with compensation linked to shareholder returns are more likely to encourage CSR disclosure. Furthermore, the analysis of other moderating variables such as media pressure or stakeholder influence on CEO power and CSR disclosure may provide more evidence about the effect of CEO power on CSR reporting. Finally, other researchers may extend our analysis by comparing how CEO power, for instance, affects CSR disclosure in different geographical areas. In particular, it would be interesting to explore the relationship between developed and developing countries, since we would expect to find differences between these two contexts.

Author Contributions: Conceptualization, M.C.P.-M. and I.G.-A.; methodology, M.C.P.-M. and I.G.A.; software, M.C.P.-M.; formal analysis, M.C.P.-M. and I.G.-A.; writing-original draft preparation, M.C.P.-M. and I.G.-A.; writing-review and editing, M.C.P.-M. and I.G.-A.; supervision, M.C.P.-M. and I.G.-A.; funding acquisition, M.C.P.-M. and I.G.-A. All authors have read and agreed to the published version of the manuscript.

Funding: The authors wish to acknowledge financial support from the Spanish Ministry of Economy, Industry, and Competitiveness for the research project ECO 2017-82259-R and from the University Jaume I for the research project UJI-B2018-15. The authors are also grateful to the Junta de Castilla $y$ León and the European Regional Development Fund (Grant CLU-2019-03) for the financial support to the Research Unit of Excellence “Economic Management for Sustainability" (GECOS).

Conflicts of Interest: The authors declare no conflict of interest.

\section{References}

1. Mark-Herbert, C.; Von Schantz, C. Communicating Corporate Social Responsibility. Electron. J. Bus. Ethics Organ. Stud. 2007, 12, 4-11.

2. Campbell, J.L. Why would corporations behave in socially responsible ways? An institutional theory of corporate social responsibility. Acad. Manag. Rev. 2007, 32, 946-967. [CrossRef]

3. Morsing, M.; Schultz, M. Corporate social responsibility communication: Stakeholder information, response and involvement strategies. Bus. Ethics 2006, 15, 323-338. [CrossRef]

4. Javeed, S.A.; Lefen, L. An Analysis of Corporate Social Responsibility and Firm Performance with Moderating Effects of CEO Power and Ownership Structure: A Case Study of the Manufacturing Sector of Pakistan. Sustainability 2019, 11, 248. [CrossRef]

5. Du, S.; Bhattacharya, C.; Sen, S. Maximizing business returns to corporate social responsibility: The role of CSR communication. Int. J. Manag. Rev. 2010, 12, 8-19. [CrossRef]

6. Friede, G.; Busch, T.; Bassen, A. ESG and financial performance: Aggregated evidence from more than 2000 empirical studies. J. Sustain. Financ. Investig. 2015, 5, 210-223. [CrossRef]

7. Busch, T.; Friede, G. The Robustness of the Corporate Social and FinancialPerformance Relation: A Second-Order Meta-Analysis. Corp. Soc. Responsib. Environ. Manag. 2018, 5, 583-608. [CrossRef]

8. Margolis, J.D.; Walsh, J.P. People and Profits?: The Search for a Link Between a Company's Social and Financial Performance; Psychology Press: New York, NY, USA, 2001.

9. Hamori, M.; Kakarika, M. External labor market strategy and career success: CEO careers in Europe and the United States. Hum. Res. Manag. 2009, 48, 355-378. [CrossRef]

10. Finkelstein, S. Power in top management team: Dimensions, measurement, and validation. Acad. J. Manag. 1992, 35, 505-538.

11. Adams, R.B.; Almeida, H.; Ferreira, D. Powerful CEOs and their impact on corporate performance. Rev. Financ. Stud. 2005, 18, 1403-1432. [CrossRef]

12. Papadakis, V.M. Do CEOs shape the process of making strategic decisions? Evidence from Greece. Manag. Sci. 2006, 44, 367-394. [CrossRef] 
13. Kanter, R.M. The middle manager as innovator. Harv. Bus. Rev. 1982, 60, 95-105. [PubMed]

14. Saidu, S. Theoretical and conceptual review of CEO power. Int. J. Acad. Manag. Sci. Res. 2019, 3, 1-18.

15. Quinn, J.B. Managing innovation: Controlled chaos. Harv. Bus. Rev. 1985, 63, 73-84.

16. Jiraporn, P.; Chintrakarn, P. How do powerful CEOs view corporate social responsibility (CSR)? An empirical note. Econ. Lett. 2013, 119, 344-347. [CrossRef]

17. Li, F.; Li, T.; Minor, D. CEO power, corporate social responsibility, and firm value: A test of agency theory. Int. J. Manag. Financ. 2016, 12, 611-628. [CrossRef]

18. Sheikh, S. An examination of the dimensions of CEO power and corporate social responsibility. Rev. Account. Financ. 2019, 18, 221-224. [CrossRef]

19. Rashid, A.; Shams, S.; Bose, S.; Khan, H. CEO power and corporate social responsibility (CSR) disclosure: Does stakeholder influence matter? Manag. Auditing. J. 2020, 35, 1279-1312. [CrossRef]

20. Hong, B.; Li, Z.F.; Minor, D. Corporate governance and executive compensation for corporate social responsibility. J. Bus. Ethics 2016, 136, 199-213. [CrossRef]

21. Jo, H.; Harjoto, M. Corporate governance and firm value: The impact of corporate social responsibility. J. Bus. Ethics 2011, 103, 351-383. [CrossRef]

22. Morck, R.; Shleifer, A.; Vishny, R.W. Management ownership and market valuation: An empirical analysis. J. Financ. Econ. 1988, 20, 293-315. [CrossRef]

23. Garcia, M.J.C.; Herrero, B. Boards of directors: Composition and effects on the performance of the firm. Econ. Res. 2018, 31, 1015-1041.

24. Astley, W.G.; Sachdeva, P.S. Structural sources of interorganizational power: A theoretical synthesis. Acad. Manag. Revi. 1984, 9, 104-113.

25. Achim, M.V.; Borlea, S.N.; Mare, C. Corporate Governance and Business Performance: Evidence for the Romanian Economy. J. Bus. Econ. Manag. 2016, 17, 458-474. [CrossRef]

26. McWilliams, A.; Siegel, D.S.; Wright, P.M. Corporate social responsibility: Strategic implications. J. Manag. Stud. 2006, 43, 1-18. [CrossRef]

27. Borlea, S.N.; Achim, V.M.; Mare, C. Board characteristics and firm performances in emerging economies. Lessons from Romania. Econ. Res. 2017, 30, 55-75. [CrossRef]

28. Freeman, R.E. Strategic Management: A Stakeholder Approach; Cambridge University Press: Cambridge, UK, 2010.

29. Harjoto, M.A.; Jo, H. Corporate governance and CSR nexus. J. Bus. Ethics 2011, 100, 45-67. [CrossRef]

30. Harper, J.; Sun, L. CEO power and corporate social responsibility. Am. J. Bus. 2019, 34, 93-115. [CrossRef]

31. Bebchuk, L.A.; Cremers, M.; Peyer, U. The CEO pay slice. J. Financ. Econ. 2011, 102, 199-221. [CrossRef]

32. Fiegener, M.K.; Brown, B.M.; Druex, D.R.V.; Dennis, W.J.J. CEO stakes and board composition in small private firms. Entrep. Theory Pract. 2000, 24, 5-24. [CrossRef]

33. Dalton, D.R.; Kesner, I.F. Composition and CEO duality in boards of directors: An international comparison. J. Intern. Bus. Stud. 1987, 18, 33-42. [CrossRef]

34. Boyd, B.K. Board control and CEO compensation. Strateg. Manag. J. 1994, 15, 335-344. [CrossRef]

35. Van Essen, M.; Otten, J.; Carberry, E.J. Assessing managerial power theory: A meta-analytic approach to understanding the determinants of CEO compensation. J. Manag. 2015, 41, 164-202. [CrossRef]

36. Jackling, B.; Johl, S. Board structure and firm performance: Evidence from India's top companies. Corp. Gov. Int. Rev. 2009, 17, 492-509. [CrossRef]

37. Muttakin, M.B.; Khan, A.; Mihert, D.G. The Effect of Board Capital and CEO Power on Corporate Social Responsibility Disclosures. J. Bus. Ethics 2018, 150, 41-56. [CrossRef]

38. Weisbach, M.S. Outside directors and CEO turnover. J. Financ. Econ. 1988, 20, 431-460. [CrossRef]

39. Fama, E.; Jensen, M. Separation of ownership and control. J. Law Econ. 1983, 26, 301-325. [CrossRef]

40. Chau, G.; Gray, S.J. Family ownership, board independence and voluntary disclosure: Evidence from Hong Kong. J. Int. Account. Audit. Tax. 2010, 19, 93-109. [CrossRef]

41. Miller, D. CEO salary increases may be rational after all: Referents and contracts in CEO pay. Acad. Manag. J. 1995, $38,1361$.

42. Peng, C.-W. The role of business strategy and CEO compensation structure in driving corporate social responsibility: Linkage towards a sustainable development perspective. Corp. Soc. Responsib. Environ. Manag. 2020, 27, 1028-1039. [CrossRef]

43. Sanders, W.M.G.; Carpenter, M.A. Internationalization and firm governance: The roles of CEO compensation, top team composition, and board structure. Acad. Manag. J. 1998, 41, 158-178.

44. Jensen, M.C.; Murphy, K.J. Performance pay and top management incentives. J. Political Econ. 1990, 98, 225-264. [CrossRef]

45. McGuire, J.; Dow, S.; Argheyd, K. CEO incentives and corporate social performance. J. Bus. Ethics 2003, 45, 341-359. [CrossRef]

46. Jouber, H. How does CEO pay slice influence corporate social responsibility? U.S.-Canadian versus Spanish-French. Corp. Soc. Responsib. Environ. Manag. 2019, 26, 502-517. [CrossRef]

47. Deckop, J.; Merriman, K.; Gupta, S. The effects of CEO pay structure on corporate social performance. J. Manag. 2006, 32, 329-342. [CrossRef]

48. Simerly, R.; Li, M.; Bass, K. CEO Compensation and Corporate Social Performance: A Longitudinal Examination. 2000. Available online: http:/ / www.westga.edu/ \{\}bquest/2000/ceo.html (accessed on 10 July 2019). 
49. Stanwick, P.; Stanwick, S. The determinants of corporate social performance: An empirical examination. Am. Bus. Rev. 1998, 16, 86-93.

50. Russo, M.V.; Fouts, P.A. A Resource-based Perspective on Corporate Environmental Performance and Profitability. Acad. Manag. J. 1997, 40, 534-560.

51. Song, W.L.; Wan, K.M. Does CEO compensation reflect managerial ability or managerial power? Evidence from the compensation of powerful CEOs. J. Corp. Financ. 2019, 56, 1-14. [CrossRef]

52. Carroll, A.B. A three-dimensional conceptual model of corporate performance. Acad. Manag. Rev. 1979, 4, 497-505. [CrossRef]

53. Bebbington, J.; Larrinaga, C.; Moneva, J.M. Corporate social reporting and reputation risk management. Account. Audit. Account. J. 2008, 21, 337-361. [CrossRef]

54. Khan, H.-U.-Z. The effect of corporate governance elements on corporate social responsibility (CSR) reporting: Empirical evidence from private commercial banks of Bangladesh. Int. J. Law Manag. 2010, 52, 82-109. [CrossRef]

55. Ehsan, S.; Nazir, M.S.; Nurunnabi, M.; Khan, Q.R.; Tahir, S.; Ahmed, I. A Multimethod approach to assess and measure corporate social responsibility disclosure and practices in a developing economy. Sustainability 2018, 10, 2955. [CrossRef]

56. Velte, P. Do CEO incentives and characteristics influence corporate social responsibility (CSR) and vice versa? A literature review. Soc. Responsib. J. 2020, 16, 1293-1323. [CrossRef]

57. Bahloul, W.; Hachicha, N.; Bouri, A. Modeling the effect of CEO power on efficiency: Evidence from the European non-life insurance market. J. Risk Financ 2013, 14, 266-285. [CrossRef]

58. Tien, C.; Chen, C.-N.; Chuang, C.-M. A study of CEO power, pay structure, and firm performance. J. Manag. Organ. 2014, 19, 424-453. [CrossRef]

59. Ali, W.; Frynas, J.; Mahmood, Z. Determinants of Corporate Social Responsibility (CSR) disclosure in developed and developing countries: A literature review. Corp. Soc. Responsib. Environ. Manag. 2017, 24, 273-294. [CrossRef]

60. Liu, X.; Anbumozhi, V. Determinant factors of corporate environmental information disclosure: An empirical study of Chinese listed companies. J. Clean. Prod. 2009, 17, 593-600. [CrossRef]

61. Dyduch, J.; Krasodomska, J. Determinants of corporate social responsibility disclosure: An empirical study of Polish listed companies. Sustainability 2017, 9, 1934. [CrossRef]

62. Pucheta-Martínez, M.C.; Gallego-Álvarez, I. An international approach of the relationship between board attributes and the disclosure of corporate social responsibility issues. Corp. Soc. Responsib. Environ. Manag. 2019, 26, 612-627. [CrossRef]

63. Prado-Lorenzo, J.M.; Gallego-Álvarez, I.; García-Sánchez, I.M. Stakeholder engagement and corporate social responsibility reporting: The ownership structure effect. Corp. Soc. Responsib. Environ. Manag. 2009, 16, 94-107. [CrossRef]

64. Martín-De Castro, G.; Amores-Salvadó, J.; Navas-López, J.E. Environmental Management Systems and Firm Performance: Improving Firm Environmental Policy through Stakeholder Engagement. Corp. Soc. Responsib. Environ. Manag. 2016, 23, 243-256. [CrossRef]

65. Arellano, M.; Bond, S. Some tests of specification for panel data: Monte Carlo evidence and an application to employment equations. Rev. Econ. Stud. 1991, 58, 277-297. [CrossRef]

66. Nyberg, A.J.; Fulmer, I.S.; Gerhart, B.; Carpenter, M.A. Agency theory revisited: CEO return and Shareholder interest alignment. Acad. Manag. J. 2010, 53, 1029-1049. [CrossRef] 